\title{
Quality Characteristics of Spicy Paneer with Oleoresins at Different Storage Temperatures
}

\author{
Mithilesh Mahadev Watharkar ${ }^{1}$, Siva Kumar S. ${ }^{1 *}$, Chatli M.K. ${ }^{2}$ and Rekha Chawla ${ }^{1}$ \\ ${ }^{1}$ College of Dairy Science and Technology, Guru Angad Dev Veterinary \& Animal Sciences University (GADVASU), \\ Ludhiana (Punjab) INDIA \\ ${ }^{2}$ Department of Livestock Products Technology, College of Veterinary Science, Guru Angad Dev Veterinary E Animal Sciences \\ University (GADVASU), Ludhiana (Punjab) INDIA \\ *Corresponding author: S Sivakumar; E-mail: sivakumarshanmugam60@gmail.com
}

Received: 01 Dec., 2020

Revised: 20 Jan., 2021

Accepted: 28 Jan., 2021

\begin{abstract}
Spicy paneer with oleoresins is the novel approach to develop tailorable ready-to-eat snack food. Oleoresins were explored to replace the original ground spice with a standardized taste and aroma as per the requirement of the product. The storage life of the developed spicy paneer was assessed at different temperatures; ambient $\left(25^{\circ} \mathrm{C}\right)$ and refrigeration temperature $\left(4^{\circ} \mathrm{C}\right)$ under aerobic packaging conditions on the basis of various sensory and physico-chemical characteristics. All the sensory attributes viz., colour and appearance, texture, flavor, chewiness and overall acceptability decreased both at the ambient and refrigeration temperature during storage. There was significant $(\mathrm{p}<0.05)$ decrease in water activity whereas increase in FFA, tyrosine and $\mathrm{pH}$ during storage at ambient and refrigerated temperature. The microbial load (SPC, Yeast and mold and coliforms) followed an increasing trend during the storage. Results concluded that the paneer was stable for a single day at ambient condition $\left(25^{\circ} \mathrm{C}\right)$ whereas 6 days at refrigeration temperature $\left(4^{\circ} \mathrm{C}\right)$ with respect to sensory and microbiological quality.
\end{abstract}

\section{HIGHLIGHTS}

(0 Sensory attributes of spicy paneer with oleoresins decreased both at the ambient and refrigeration temperature during storage.

0 Microbial load followed an increasing trend during the storage.

(0 Spicy paneer with oleoresins was stable for a single day at ambient condition $\left(25^{\circ} \mathrm{C}\right)$ whereas 6 days at refrigeration temperature $\left(4^{\circ} \mathrm{C}\right)$ with respect to sensory and microbiological quality.

Keywords: Spicy paneer, Oleoresins, Storage study, Aerobic Packaging

Paneer is a popular indigenous product and almost $7 \%$ of the total milk in India is used for paneer production. Though, it is consumed throughout India, however, North India accounts for $55-60 \%$ whereas western and southern region accounts for only 15-20 per cent each of total demand. Majority of the paneer production is in unorganised or and marketed as unbranded product $(>95 \%)$ whereas remaining as branded product $(<5 \%)$. The trade market forecast the branded paneer market will grow at $20-25 \%$ annually in terms of value, as major dairy industry players are expected to take up retail marketing with automated manufacturing facility (Anonymous, 2015b). The key factors to successful branded paneer marketing include good taste, premium quality and a longer shelf life in the retail segment.

Since ages, paneer has been used as a delicacy that can be used in the preparation of a variety of culinary dishes and snacks. However, the bland taste of paneer is the main drawback for consumer acceptability; and the problem can be eliminated by introducing with added taste enhancers as with spicy paneer. Presently, spicy paneer is prepared

How to cite this article: Watharkar, M.M., Siva Kumar, S., Chatli, M.K and Chawla, R. (2021). Quality characteristics of spicy paneer with oleoresins at different storage temperatures. J. Anim. Res., 11(1): 97-103. Source of Support: None; Conflict of Interest: None 
at household or small-scale level with the incorporation of available herbs like coriander, mint leaves, green chilies, roasted and grinded cumin seeds, and black pepper. However, the quality and flavor of resultant paneer varies every time with erroneous weight changes in formulation, variation in composition of added spices due to ageing or climatic variations. In this regard, spicy paneer using oleoresins is the new ready to eat snack food. Oleoresins can replace the original ground spice with a standardized taste and aroma that can be tailored as per the requirement of the product. Oleoresins can be defined as the pure extracts of the spices/herb and can replace whole/ground spices without impairing any flavor and characteristic aroma (Paul, 2005). These are obtained from spices by extraction with a non-aqueous solvent followed by removal of the solvent by evaporation. They are concentrated natural liquid flavorings that contain both volatile and non-volatile flavor components with advantage of being economical, easy quality control, requiring lesser storage space, longer shelf-life, no or zero bacterial contamination and are a convenient substitute for ground spices (Anonymous, 2015).

\section{MATERIALS AND METHODS}

For the preparation of spicy paneer, mixed milk was collected from Experimental Dairy Plant, CODST, GADVASU, Ludhiana and was standardized before preparation of the spicy paneer. Four oleoresins were procured from Plant Lipids Pvt. Ltd. company from Cochin. (Ginger Oleoresins, Green Chilli Oleoresins, Cumin Oleoresins and Black Pepper Oleoresins). Low density polyethylene (LDPE) film was used for packaging of samples during storage study. All the chemicals used in the study were of analytical grade.

\section{Preparation methodology}

The paneer was prepared in the laboratory using method described by Bhattacharya et al. (1971) with slight modifications for incorporation of fat-soluble oleoresins (Ginger, Green chili, Cumin and Black Pepper oleoresins) were added and mixed thoroughly with suitable methods.

\section{Physicochemical, microbiological Analysis}

The brief description of different methods used to examine physico-chemical, microbiological properties of spicy paneer is given here under.

The moisture content in spicy paneer was determined by standard gravimetric method as described in Indian standards (1981). The titratable acidity and ash content were determined as per method of AOAC (2006). The samples of spicy paneer were analysed using Aqua Lab for water Activity (Series 4TE) and the method prescribed by Deeth et al. (1975) was used to estimate the FFA content, Hull, (1947) method was used to estimate the Tyrosine value of spicy paneer.

Standard plate count, yeast and mold count and coliform count were recorded as per procedure by Wehr and Frack (2004)

\section{Storage study}

Spicy paneer was packed in LDPE and stored at refrigeration temperature $\left(4 \pm 1^{\circ} \mathrm{C}\right)$ in a refrigerator (make: LG) and controlled ambient temperature $\left(25 \pm 1^{\circ} \mathrm{C}\right)$ in a stability chamber (Make: Remi) for shelf-life estimation. Stored product was evaluated for sensory, physicochemical, microbiological count at 3 days interval for refrigerated product and one day interval for controlled ambient temperature product.

\section{RESULTS AND DISCUSSION}

\section{Storage study of the optimized spicy paneer}

For the storage study, each block of $250 \mathrm{~g}$ paneer of optimized spicy paneer was packed in LDPE pouches in aerobic packaging and kept at two different temperatures viz. controlled ambient temperature $\left(25 \pm 1^{\circ} \mathrm{C}\right)$ and refrigeration temperature $\left(4 \pm 1^{\circ} \mathrm{C}\right)$ till the spoilage of product. The product was analyzed for its sensory attributes, physico-chemical properties, microbiological parameter at the regular interval of one day for samples stored at ambient and three days for refrigeration temperatures, respectively.

\section{Effect of storage on sensory properties of spicy paneer}

During storage, all the sensory attributes viz., colour and appearance, texture, flavor, chewiness and overall acceptability, decreased at the ambient and refrigeration 
temperature (Fig. 1 to 2). However, the declining trend was more prominent and sharper at ambient temperature compared to refrigerated temperature while considering the interval pattern. Colour and appearance scores for 0 day (8.03) decreased to (7.95) after 24 hours at ambient temperature (Fig. 1) while it decreased from 8.03 to 7.41 after 6 days of storage at refrigeration temperature using aerobic packaging (Fig. 2). Appearance of the product was slightly dull and dry attributing to moisture loss during storage. Similarly, chewiness and texture scores at ambient temperature decreased from 7.73 to 7.41 and 7.61 to 7.35 respectively (Fig. 1).

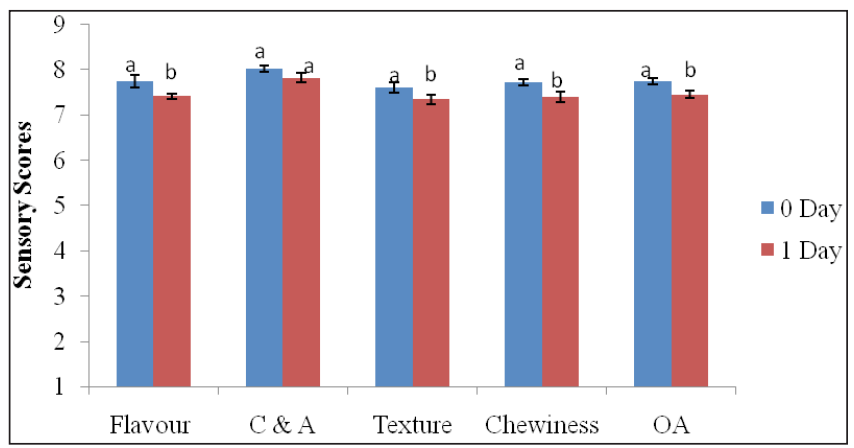

Fig. 1: Effect of storage period on sensory attributes of spicy paneer stored at controlled ambient temperature $\left(25 \pm 1^{\circ} \mathrm{C}\right)$

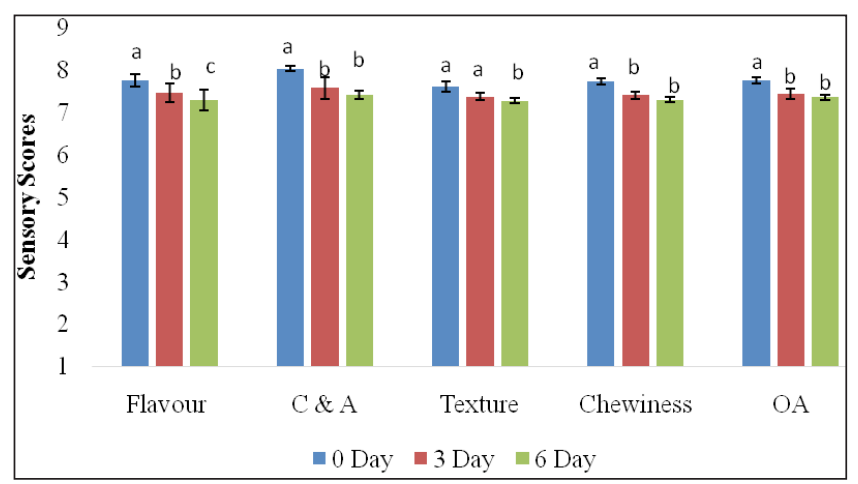

Fig. 2: Effect of storage period on sensory attributes of spicy paneer stored at refrigerated temperature $\left(4 \pm 1^{\circ} \mathrm{C}\right)$

During storage at ambient temperature, the appearance of spicy paneer was affected and was not acceptable which ultimately led to the non-acceptability quality of the spicy paneer. The flavor scores also decreased significantly at both the temperature during the storage. The flavour scores decreased from 7.75 to 7.28 under refrigerated packaging over a period of 6 days and the probable reason for significant decrease in the flavour score of the product could be due to increase in acidity and rancidity of the product. Product lost its freshness and peculiar taste as well, claiming to development of acidity, oxidation of fat or proteolysis of proteins. Psychotropic organism might also pose a serious problem in arising defects like high acidity, gas formation during storage at low temperature. The texture scores declined significantly $(\mathrm{p}<0.05)$ after 6 day of storage period at refrigerated conditions with scores falling from 7.61 to 7.27. Here, loss of moisture content is the prime reason leading to lack of freshness and increased hardening of the product, making the lesser acceptable textural changes contributing towards lesser sensory ranking. There was significant change in chewiness scores during refrigerated storage however gradual and significant $(p<0.05)$ decline in the overall acceptability scores was reported at ambient and refrigeration temperature. The overall acceptability scores decreased from 7.75 to 7.35 at refrigeration temperature while it decreased to 7.46 after 24 hours only. Thachil and Rajakumar (2015) also reported similar results of decrease in sensory scores for spicy paneer prepared from oleoresins during storage.

\section{Effect of storage period on physico-chemical parameters}

The physico-chemical properties help in determining the changes occurring during the storage period (Fig. 3 and 4). It gives an idea about the shelf life and also helpful in making strategy for commercialization of the newly developed dairy products. For measuring the change in physico-chemical properties of the product, samples were analyzed for moisture, water activity, tyrosine value, free fatty acids, acidity and $\mathrm{pH}$ after a regular interval of 24 hours/day at ambient temperature and 3 days at refrigeration temperature.

There was a significant $(\mathrm{p}<0.05)$ difference in the moisture content of the optimized product during storage period at refrigerated temperature. The higher moisture content of this product was a key reason towards its faster spoilage resulting in limited shelf life. The shelf-life of paneer was only 1 day at controlled ambient temperature $\left(25 \pm 1^{\circ} \mathrm{C}\right)$ wherein the spoilage was mainly attributed to the growth of surface tainting and off-flavour producing microbes. Though the moisture content fell during storage but still 

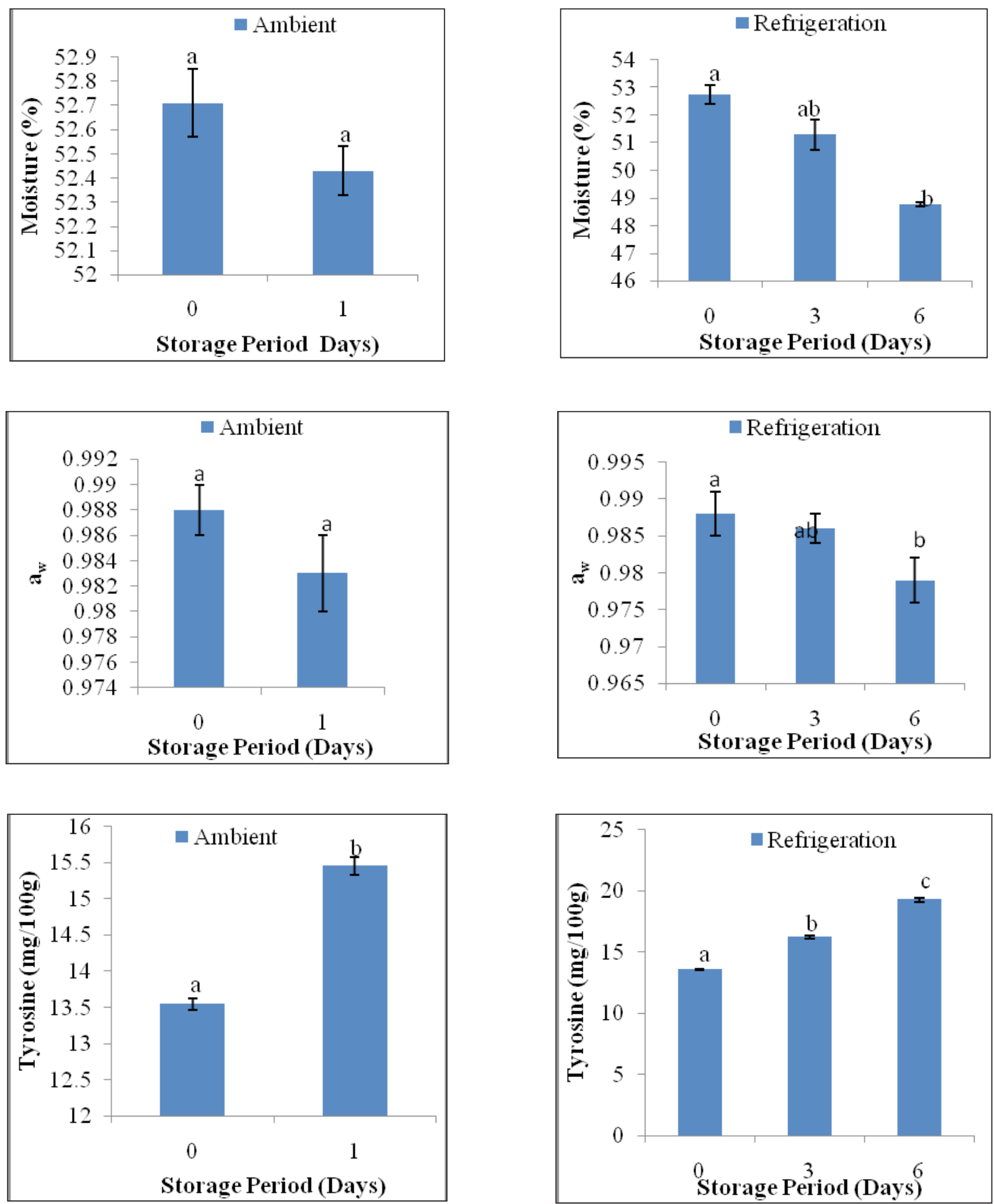

Fig. 3: Effect of storage period on moisture, water activity and tyrosine value of spicy paneer at controlled ambient $\left(25 \pm 1^{\circ} \mathrm{C}\right)$ and refrigeration temperature $\left(4 \pm 1^{\circ} \mathrm{C}\right)$ 

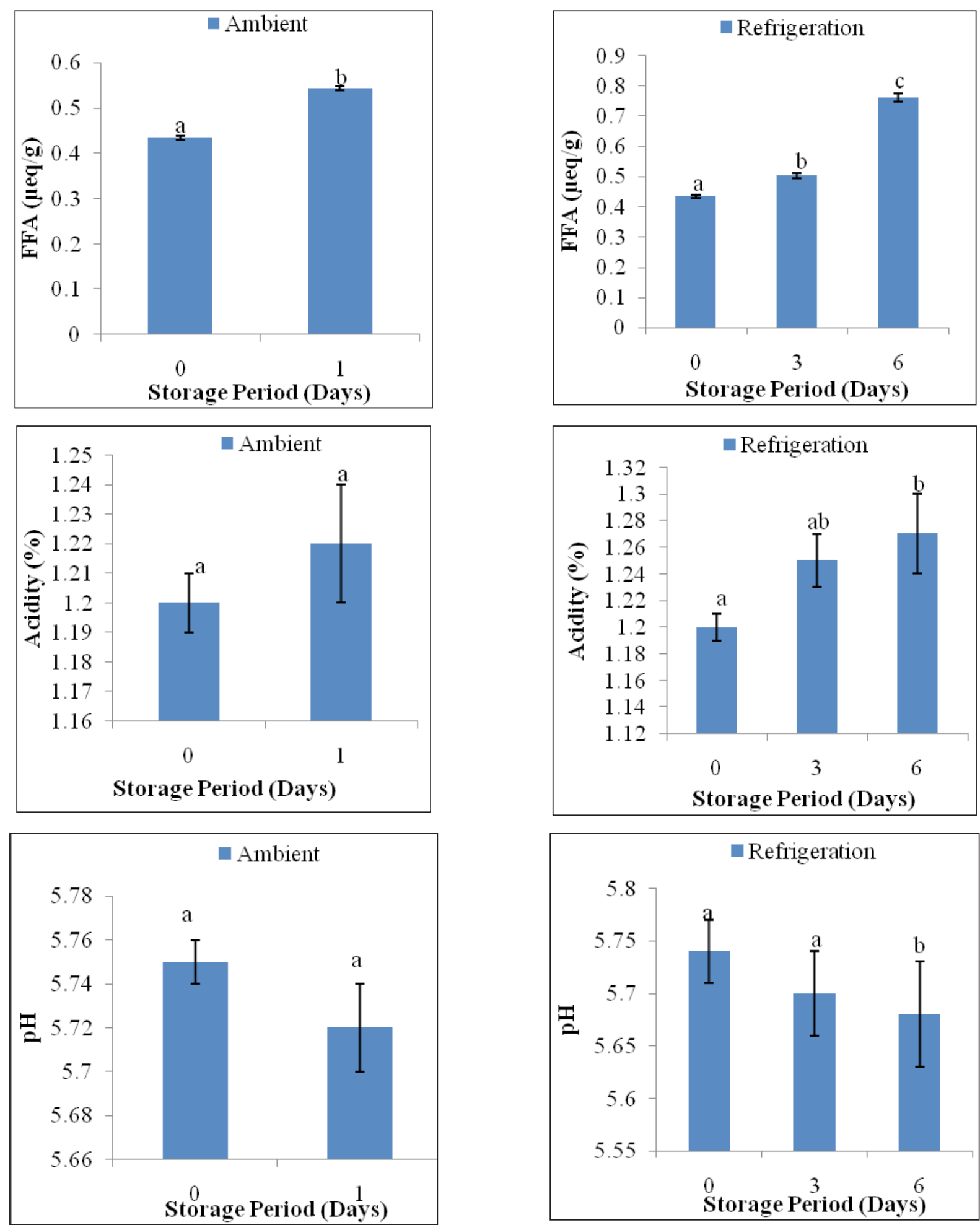

Fig 4: Effect of storage period on FFA, per cent acidity and $\mathrm{pH}$ of spicy paneer at controlled ambient $\left(25 \pm 1^{\circ} \mathrm{C}\right)$ and refrigeration temperature $\left(4 \pm 1^{\circ} \mathrm{C}\right)$ 
the residing moisture was found enough for proliferation of microbes and ultimate spoilage of the product. Refrigerated product showed a gradual but declining trend from 52.75 to 48.78 (Fig. 3) statistically different in every interval. Changes in water activity was quite evident during storage at both the temperature, attributed to loss of moisture from the product during storage. The water activity decreased from 0.988 to 0.983 at ambient temperature and 0.988 to 0.979 at refrigeration temperature after 6 days interval.

Tyrosine value of spicy paneer was analysed at both temperature conditions, a measure of degree of proteolysis. The proteases indigenous to milk and as well as microbial proteases degrade proteins which lead to release of free amino acids like tyrosine and peptides, producing bitter taste in dairy products. In spicy paneer, protein was the major resource for proteases and the value increased from $13.54 \mathrm{mg} / 100 \mathrm{~g}$ to $15.45 \mathrm{mg} / 100 \mathrm{~g}$ at ambient temperature under ambient conditions compared to increase in value up to 19.25 in refrigerated samples (Fig. 3). The increase in tyrosine value indicates proteolysis reactions occurring during storage period leading to slight bitter taste in the product. There was a significant $(p<0.05)$ change in tyrosine value at both the tested temperatures under aerobic packaging.

The increase in free fatty acids during storage indicated splitting of fat present in product leading to rancid and off flavours. The free fatty acid values increased from $0.433 \mu \mathrm{eq} / \mathrm{g}$ to $0.543 \mu \mathrm{eq} / \mathrm{g}$ at ambient temperature and to $0.761 \mu \mathrm{eq} / \mathrm{g}$ at refrigeration temperature (Fig. 4). Lipid hydrolysis, which causes cleavage of triglycerides thereby releasing short and medium chain fatty acids, is one of the most serious defects which lead to undesirable rancid flavour in the product (Shahin and Fahmy, 1998). These indigenous milk lipases can be inactivated by heat treatment during preparation of spicy paneer and it is mainly microbial and fungal lipases which are responsible for release of FFA in dairy products during storage (Bills et al., 1969). Results indicated statistically significant increase in free fatty acids $(\mathrm{p}<0.05)$ during storage period. It is clearly evident that there was significant $(p<0.05)$ change in acidity during storage at refrigeration temperature under prevailing aerobic conditions.

While $\mathrm{pH}$ has an inverse relation with acidity, fall in $\mathrm{pH}$ was observed during storage period at both the temperatures. Microorganism's activity caused decrease in $\mathrm{pH}$ of spicy paneer in which fell further with an advancement of the storage period and decreased from 5.75 to 5.72 within 24 hours at ambient temperature and to 5.68 at refrigeration temperature after 6 days period.

\section{Effect of storage on microbiological parameters}

The microbial results showed a synchronization with the sensory evaluation of the product during storage. The low shelf-life of spicy paneer at ambient temperature is mainly due to microbial and physico-chemical changes. The microbiological change in spicy paneer during storage has been presented in Table 1. In most of the dairy products, mold growth is the major limiting factor. The increase in SPC was majorly attributed to favourable environmental factors like temperature, relative humidity, storage conditions and food factors like $\mathrm{pH}$, water activity, moisture and nutrients present. The standard plate count of spicy paneer increased significantly $(p<0.05)$ during storage at ambient temperature to $1.02 \mathrm{log} \mathrm{cfu} / \mathrm{g}$ while at refrigeration temperature the increase was significant during evaluated intervals and up to $6^{\text {th }}$ days of storage $(\mathrm{p}<0.05)$ which rose to $4.49 \mathrm{log} \mathrm{cfu} / \mathrm{g}$ on $6^{\text {th }}$ day of storage at refrigerated temperature. Yeast and mold count in fresh product were not detected. Increase in

Table 1: Effect of storage period on microbiological properties of spicy paneer stored at ambient and refrigeration temperature $\left(4 \pm 1^{\circ} \mathrm{C}\right)$ (Aerobic Packaging)

\begin{tabular}{lllccc}
\hline $\begin{array}{l}\text { Microbiological } \\
\text { parameters }\end{array}$ & $\mathbf{0}$ & $\mathbf{1}$ & \multicolumn{3}{c}{ Storage Period (Days) } \\
\cline { 2 - 6 } Temperature & Controlled Ambient & \multicolumn{2}{c}{$\mathbf{0}$} & $\mathbf{3}$ & $\mathbf{6}$ \\
\hline SPC & Nil & & & Refrigeration temperature $\left.\mathbf{( 4} \pm \mathbf{1}^{\circ} \mathbf{C}\right)$ \\
Coliform & Nil & $1.02 \pm 0.01$ & Nil & $3.62 \pm 0.18^{\mathrm{a}}$ & $4.49 \pm 0.04^{\mathrm{b}}$ \\
Yeast and mold & Nil & Nil & Nil & Nil & $1.20 \pm 0.05^{\mathrm{a}}$ \\
\hline
\end{tabular}

Means with different superscripts differ significantly $(\mathrm{p}<0.05)$; Values are expressed in log cfu/g and all values are expressed as Mean $\pm \mathrm{SD}$. 
acidity during storage leads to favourable environment for the growth and multiplication of yeast and mold, therefore no mold growth was obtained at ambient temperature and same happened with the coliform count which was nil for $1^{\text {st }}$ day at ambient temperature. However, at refrigerated storage, coliform count increased from nil to $1.20 \log \mathrm{cfu} / \mathrm{g}$ on $6^{\text {th }}$ day while yeast and mold rose to $2.07 \mathrm{log} \mathrm{cfu} / \mathrm{g}$ from nil. The product was unacceptable after $6^{\text {th }}$ days of storage period at refrigerated temperature owing to microbial counts which exceeded the standards of FSSR, (2011).

\section{CONCLUSION}

From the obtained results, it can be concluded that refrigerated storage is a viable option for extending the newer kind of dairy product i.e. spicy paneer prepared using oleoresins with intact sensory and microbiological parameters. Oleoresins not only simulate the original flavor of the spices but also eliminate the differences in lot to lot variation existing otherwise in raw spices as a whole. Such newer varieties can be launched into the market for varietal options and delicacy for consumers, who otherwise got bored of bland taste of paneer.

\section{REFERENCES}

Anonymous, 2015. Spice Oleoresins. Food and Beverage magazine.

Anonymous, 2015b. Status of dairy industry in India \& animal population-review. http://www.indiaagronet.com/ indiaagronet/DAIRY/Dairy.htm.

AOAC. 2006. Official methods of analysis, $15^{\text {th }}$ Edn. Association of Official Analytical Chemists, Washington, DC.
Bhattacharya, D.C., Mathur, O.N., Srinivasan, M.R. and Samlik. O. 1971. Studies on the method of production and shelf-life of paneer (cooking type of acid coagulated cottage cheese). $J$. Food Sci. Technol., 8: 117-120.

Bills, D.D., Scantan, R.A., Lindsay, R.C. and Sather, L. 1969. Free fatty acids and the flavor of dairy products. J. Dairy Sci., 52(8): 1340-45.

Deeth, H.C., Fitz-Gerald, C.H. and Wood, A.F. 1975. A convenient method for determining the extent of lipolysis in milk. Australian J. Dairy Tech., 30(3): 109-11.

FSSR, 2011. Food Safety and Standard Regulations. Food Safety and Standard Authority of India, Ministry of Health and Family Welfare, Govt. of India, New Delhi (Accessed on 4.4.2016)

Hull, M.E. 1947. Studies on milk proteins: Colorimetric determination of the partial hydrolysis of the proteins in milk. J. Dairy Sci., 30: 881-84.

IS: SP 18 (Part XI) 1981. Handbook of food analysis. Part XI, Dairy Products. Bureau of Indian Standards. Manak Bhavan, New Delhi.

Paul, G. 2005. India's Spice Oleoresin Industry, Paper presented at the IFEAT Conference in Cochin, India, 16-20 October 2005, pp. 2-9.

Shahin, Y and Fahmy, M.A. 1998. Lipolysis and proteolysis in UHT treated recombined milk during storage. Egyptian J. Dairy Sci., 16:191-99.

Thachil, G.A. and Rajakumar, S.N. 2015. Effect of different concentration of brine on the sensory quality of spiced paneer. Indian J. Appl. Res., 5(2).

Wehr, H.M. and Frank, J.F. 2004. 'Standard Methods for the Examination of Dairy Products'. 17 $7^{\text {th }}$ ed. Am. Public Health Association, Washington, DC. 
